\title{
Review
}

\section{Interaction of viral proteins with host cell death machinery}

\author{
David J. Granville ${ }^{1,2,4}$, Chris M. Carthy ${ }^{1,4}$, Decheng Yang ${ }^{1}$, \\ David W.C. Hunt ${ }^{1,2}$ and Bruce M. McManus ${ }^{1,3}$ \\ ${ }^{1}$ Cardiovascular Research Laboratory, University of British Columbia, St. Paul's \\ Hospital, Vancouver, British Columbia, Canada \\ 2 QLT PhotoTherapeutics Inc., Vancouver, British Columbia, Canada \\ ${ }^{3}$ corresponding author: Bruce McManus, Department of Pathology and \\ Laboratory Medicine, Cardiovascular Research Laboratory, University of \\ British Columbia, St. Paul's Hospital, 1081 Burrard Street, Vancouver, B.C., \\ Canada V6Z 1 Y 6 \\ tel.: (604) 631-5200; fax: (604) 631-5208; e-mail: mcmanus@unixg.ubc.ca \\ ${ }^{4}$ authors contributed equally to this work.
}

Received 23.12.97; revised 4.3.98; accepted 13.3.98

Edited by D. Vaux

\begin{abstract}
In recent years, intense research has been directed towards understanding molecular mechanisms involved in viral pathogenesis. It is now known that many viruses manipulate host defense mechanisms to prevent apoptosis in order to maximize viral replication. Towards the end of their replication cycle, certain viruses direct the synthesis of proteins that induce apoptosis or cell lysis thereby facilitating viral release from the cell. The present review summarizes the current understanding of interactions between viral proteins and the host cell death machinery.
\end{abstract}

Keywords: apoptosis; virus; cytopathic effect; viral persistence

\begin{abstract}
Abbreviations: ADP, adenovirus death protein: Apaf-1, apoptotic protease activating factor-1; BHRF1, BamHI fragment $\mathrm{H}$ rightward reading frame 1 ; cyt $c$, cytochrome $c$; DFF, DNA fragmentation factor; FADD, Fas-associated death domain protein; FLICE, FADDlike interleukin-1 $\beta$ converting enzyme; FLIP, FLICE inhibitory protein; HBV, hepatitis $B$ virus; IAP, inhibitor of apoptosis protein; $\mathrm{I} \kappa \mathrm{B}$, inhibitor $\kappa \mathrm{B}$ protein; IKK- $\alpha, \mathrm{I}_{\kappa} \mathrm{B}-\alpha$ kinase; LMP-1, latent membrane protein-1; NF- $\kappa \mathrm{B}$, nuclear factor- $\kappa \mathrm{B}$ : NIK, NF- $\kappa \mathrm{B}$ inducing kinase; ORF16, open reading frame 16; PARP, poly (ADP-ribose) polymerase; $\mathrm{Rb}$, retinoblastoma protein; $\mathrm{TNF}$, tumor necrosis factor; TRAF-2, TNF receptor associated factor-2.
\end{abstract}

\section{Introduction}

Virologists have long believed that viruses produce their cytotoxic and lethal effects by disrupting the cellular transcriptional or translational machinery or by altering membrane integrity of the host cell (Hardwick, 1997). Although such processes do account for the adverse effects produced by certain viruses towards host cells, there is a growing recognition that many viruses kill cells by triggering apoptosis. Conversely, it is also known that viruses may exploit apoptotic pathways to achieve viral latency or to preserve the viability of the host cell, thereby prolonging the duration of viral replication (Rudin and Thompson, 1997). In this regard, many viruses induce apoptosis only during the late stages of infection (Teodoro and Branton, 1997). In fostering cellular integrity, certain viruses find a favorable long-term niche in the host. Persistence allows viruses the opportunity to 'optimize' replication, while controlling the release of viral progeny and the nature of immune perturbation.

Many of the morphological and biochemical changes that occur during virus-induced apoptosis in cell culture systems do not differ greatly from those observed using other unrelated pro-apoptotic stimuli. Apoptosis is characterized by cell shrinkage, chromatin condensation, DNA fragmentation and the formation of apoptotic bodies. Caspases (cysteinyl aspartate proteinases) are believed to play a significant role in the proteolytic cleavage of certain structural and functional proteins which may contribute to the manifestation of the apoptotic phenotype (Nicholson and Thornberry, 1997). Membrane-enclosed apoptotic bodies are recognized and engulfed by adjacent, normally non-phagocytic cells as well as by phagocytic cells (Hardwick, 1997). However, in certain tissues, the extent of apoptosis may be so profound that the number of healthy, uninfected cells capable of phagocytosis is insufficient to handle the burden of apoptotic cells. The accumulation of apoptotic vesicles bearing viral antigens, accompanied by the gradual disintegration and lysis of non-phagocytosed apoptotic bodies may be major factors in the evocation of inflammatory responses associated with many viral infections. Thus, unlike most non-infectious forms of apoptosis or programmed cell death, virus-induced apoptosis can elicit a non-specific inflammatory response as apoptosis and necrosis merge.

In the present mini-review, we will focus on interactions of viral proteins with specific host proteins that determine the fate of the virus and the infected cell, primarily based on events which serve to promote or inhibit an apoptotic response. We will assess strategies utilized by viruses to target and modulate the activity of regulatory proteins in the death pathway.

\section{Viral proteins that inhibit apoptosis}

Prior to the formation of specific anti-viral cellular or humoral immune responses, the induction of apoptosis may represent an early protective host cell response, eliminating virus-infected cells and limiting viral reproduction (Rudin and Thompson, 1997). Alternatively, many viruses have evolved exquisite strategies to inhibit 
Table 1 Viral proteins that inhibit apoptosis

\begin{tabular}{|c|c|c|}
\hline Virus & Protein & Function \\
\hline \multicolumn{3}{|l|}{ Adenoviridae } \\
\hline \multirow{7}{*}{ Adenovirus } & E1B-19K & Bcl-2-like function (Farrow et al, 1995) \\
\hline & & Binds to nuclear lamins (Rao et al, 1997) \\
\hline & E1B-55K & Binds to p53 targeting it for degradation (Yew et al, 1994) \\
\hline & E3-14.7K & Inhibits TNK $\alpha$-induced cytolysis (Tufariello et al, 1994) \\
\hline & E3-10.4K/14.5K & Downregulation of Fas on cell surface (Shisler et al, 1997) \\
\hline & & Inhibits TNF-induced release of arachidonic acid (Krajcsi et al, 1996) \\
\hline & & $\begin{array}{l}\text { Inhibits TNF-induced translocation of cytosolic PLA2 to membranes } \\
\text { (Dimitrov et al, 1997) }\end{array}$ \\
\hline \multicolumn{3}{|l|}{ Unnamed DNA virus famliy } \\
\hline African swine fever virus & A179L, LMW5-HL & Bcl-2 homologue (Neilan et al, 1993; Revilla et al, 1997) \\
\hline & A224L & IAP homologue (Chacon et al, 1995) \\
\hline \multicolumn{3}{|l|}{ Baculoviridae } \\
\hline \multirow[t]{3}{*}{ Baculovirus } & p35 & Caspase inhibitor (Bertin et al, 1996) \\
\hline & IAP & May bind TRAFs (Uren et al, 1996) \\
\hline & & May inhibit caspases (Devereaux et al, 1997) \\
\hline \multicolumn{3}{|r|}{ 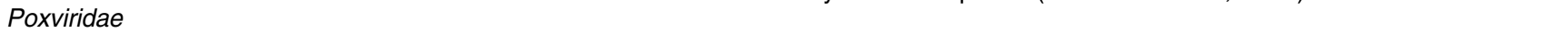 } \\
\hline Cowpox virus & crmA & $\begin{array}{l}\text { Serpin, caspase inhibitor (Antoku et al, 1997; Komiyama et al, 1994; } \\
\text { Ray et al, 1992; Zhou et al, 1997) }\end{array}$ \\
\hline Molluscum contagiosum virus & FLIP (vFLIP, MC159) & Inhibits caspase-8 activation (Bertin et al, 1997; Hu et al, 1997; \\
\hline \multirow[t]{2}{*}{ Rabbit poxvirus } & SPI-1, SPI-2 & Serpins (Brooks et al, 1995) \\
\hline & & Caspase inhibitor (Kettle et al, 1997) \\
\hline \multirow[t]{2}{*}{ Vaccinia virus } & E3L & $\begin{array}{l}\text { dsRNA-binding protein that inhibits interferon-induced Protein kinase } \\
\text { PKR (Ho and Shuman, 1996) }\end{array}$ \\
\hline & SPI-2 & Serpin, homology to crmA (Dobbelstein and Shenk, 1996) \\
\hline Myxoma virus & M-T2 & $\begin{array}{l}\text { TNF receptor (p55) homologue. Inhibit extracellular TNF binding and } \\
\text { intracellular induced apoptosis (Schreiber et al, 1997; Sedger and } \\
\text { McFadden, 1996) }\end{array}$ \\
\hline \multicolumn{3}{|l|}{ Herpesviridae } \\
\hline Human herpesvirus 1 & US3 & Protein kinase (Leopardi et al, 1997) \\
\hline Equine herpesvirus 2 & FLIP (E8) & Upstream inhibitor of caspase-8 (Bertin et al, 1997; Hu et al, 1997) \\
\hline \multirow{3}{*}{$\begin{array}{l}\text { Human herpesvirus } 4 \\
\text { (Epstein-Barr virus) }\end{array}$} & BHRF1 & Bcl-2 homologue (McCarthy et al, 1996) \\
\hline & LMP1 & Interacts with TRAFs (Devergne et al, 1996) \\
\hline & & Induces expression of Bcl-2 and A20 (Fries et al, 1996) \\
\hline $\begin{array}{l}\text { Human herpesvirus } 5 \\
\text { (Cytomegalovirus) }\end{array}$ & $1 \mathrm{E} 1,1 \mathrm{E} 2$ & Transcription factors (Zhu et al, 1995) \\
\hline \multirow[t]{2}{*}{ Human herpesvirus 8} & KSbcl-2 & Bcl-2 homologue (Cheng et al, 1997) \\
\hline & FLIP (vFLIP) & Inhibits caspase-8 activation (Thome et al, 1997) \\
\hline \multirow[t]{2}{*}{ Saimirine herpesvirus 2} & ORF16 & Bcl-2 homologue (Nava et al, 1997) \\
\hline & FLIP (vFLIP) & Inhibits caspase-8 activation (Thome et al, 1997) \\
\hline Bovine herpesvirus 4 & FLIP (BORFE2) & Inhibits caspase-8 activation (Wang et al, 1997) \\
\hline \multicolumn{3}{|r|}{ Iminions caspase-o activation (vvang el al, 1997) } \\
\hline SV40 & Full length Large T Antigen & $\begin{array}{l}\text { Andenovirus E1B } 19 \mathrm{~K} \text { homology. Blocks apoptosis independently of } \\
\text { p53 inactivation (Conzen et al, 1997) }\end{array}$ \\
\hline Poliomavirus & small $\mathrm{T}$ antigen & Decreased sensitivity to TNF- $\alpha$ (Bergqvist et al, 1997) \\
\hline
\end{tabular}

apoptosis (Table 1) providing avenues to enhance viral replication or establish persistence in select cells (Thomson, 1995).

Interaction of specific viral proteins with components of the apoptotic pathway provides a basis for influencing the dynamic balance between life and death in cells, elimination or persistence of virus and the development of transient or sustained immunological and inflammatory responses. Molluscum contagiosum virus, equine herpesvirus 2, bovine herpesvirus 4, human herpesvirus 8 and herpesvirus saimiri contain FLICE-inhibitory proteins (FLIPs) which possess FLICE (caspase-8)-homologous sequences that interact with the adapter Fas-associated death domain protein (FADD) (Bertin et al, 1997; Hu et al, 1997; Senkevich et al, 1997; Thome et al, 1997). This FLIP-FADD interaction serves to block caspase-8 activation and downstream events induced by the binding of Fas or
TNF receptor to their respective ligands (Thome et al, 1997). Expression of the cowpox serpin CrmA (cytokine response modifier $\mathrm{A}$ ) has been shown to block caspase-8mediated activation of downstream caspases including caspase-1 and caspase-3 (Srinivasula et al, 1996; Zhou et al, 1997). The IAPs (inhibitor of apoptosis proteins) constitute a family of proteins found in baculoviruses which, when expressed can block apoptosis induced by viral infection or by caspase-1 (Yuan, 1997). Although the antiapoptotic mechanism of viral IAPs is not fully understood, evidence has shown that IAPs may interact with TNF receptor associated factor-2 (TRAF-2) (Uren et al, 1996). Furthermore, cellular IAPs are direct inhibitors of caspases and have been shown to bind directly to caspase-3 and -7 (Devereaux et al, 1997).

Several viruses have evolved strategies to block the action of tumor suppressor genes such as p53 and the 
retinoblastoma protein $(\mathrm{Rb})$ (Teodoro and Branton, 1997). For DNA viruses, this blockade may be necessary to regulate host cell DNA synthetic machinery and cell cycle progression (Cuff and Ruby, 1996; Teodoro and Branton, 1997). Such regulation of host DNA synthesis is exemplified by human adenoviruses ( $\mathrm{Li}$ et al, 1997), Simian virus 40 (Conzen et al, 1997), human papillomaviruses (HPV) (Brown et al, 1997) and hepatitis $B$ viruses (HBV) (Chirillo et al, 1997).

Certain viral genomes encode proteins with highly conserved domains characteristic of Bcl-2-related proteins. These $\mathrm{Bcl}-2$ homologous $(\mathrm{BH})$ regions may dimerize or interact with other proteins within the Bcl-2 family. The Epstein Barr virus BHRF1 and adenovirus E1B-19 kDa proteins are Bcl-2 homologues (Chiou et al, 1994; Henderson et al, 1993). E1B-19 kDa has been shown to interact with and inhibit apoptosis induced by pro-apoptotic Bcl-2 family members such as Bax, Bak and Bik (Rao et al, 1997). Sequence analysis has identified a novel viral anti-apoptotic Bcl-2 homologue, designated $\mathrm{KSbcl}-2$, from human herpesvirus 8 (HHV8) or Kaposi sarcoma-associated herpesvirus that does not homo-dimerize or hetero-dimerize with other $\mathrm{Bcl}-2$ proteins (Cheng et al, 1997). KSbcl-2, may have evolved to evade the pro-apoptotic negative regulatory effects of host Bax and Bak proteins (Cheng et al, 1997).

\section{Viral proteins that induce apoptosis}

The mechanisms by which viral proteins interact with host cellular proteins to produce apoptotic cell death are not as well-defined as those for viral proteins that inhibit apoptosis. However, viruses are capable of utilizing several diverse mechanisms to promote apoptosis (Table 2). Certain viruses induce apoptosis through the direct action of specific viral proteins (Rao et al, 1992), while other viruses may indirectly induce cell death by blocking host transcriptional or translational mechanisms (Barco and Carrasco, 1995).

Although specific viral proteins are implicated in the induction of apoptotic cell death, others have been shown to promote necrotic cell death. Adenoviruses are wellknown for their ability to cause viral protein-induced necrosis. Adenoviruses typically infect quiescent cells which do not support viral replication (Hardwick, 1997). The adenovirus E1A protein drives the infected cells into Sphase, promoting viral DNA replication, but also inadvertently induces apoptosis (Rao et al, 1992; Wold, 1993).

Table 2 Viral proteins that induce or facilitate apoptosis

\begin{tabular}{|c|c|c|}
\hline Virus & Protein & Function \\
\hline \multicolumn{3}{|l|}{ Adenoviridae } \\
\hline \multirow[t]{3}{*}{ Adenovirus } & E1A & $\begin{array}{l}\text { Binds Rb and p300, and induces cell cycle progression (Liu and Kitsis, } \\
\text { 1996) }\end{array}$ \\
\hline & E3/ADP & Required for cell lysis (Tollefson et al, 1996a) \\
\hline & E4orf6 & Regulates p53 stability (Querido et al, 1997) \\
\hline \multicolumn{3}{|l|}{ Unnamed DNA virus family } \\
\hline African Swine Fever Virus & $5 E L$ & $\begin{array}{l}\text { I } \kappa \mathrm{B} \text { homologue, downregulation of } \mathrm{NF}-\kappa \mathrm{B} \text { gene expression (Neilan et } \\
\text { al, 1997) }\end{array}$ \\
\hline \multicolumn{3}{|r|}{ (1) } \\
\hline Baculovirus & IE-1 & Transcription factor (Prikhod'ko and Miller, 1996) \\
\hline \multicolumn{3}{|r|}{ 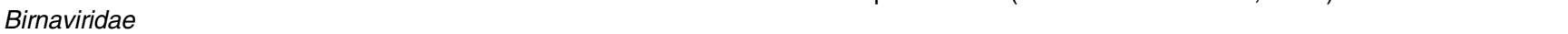 } \\
\hline Infectious bursal disease virus & VP2 & Viral capsid protein (Fernandez-Arias et al, 1997) \\
\hline \multicolumn{3}{|l|}{ Circoviridae } \\
\hline Chicken anemia virus & Apoptin & Nuclear binding protein (Zhuang et al, 1995a) \\
\hline \multicolumn{3}{|l|}{ Coronaviridae } \\
\hline $\begin{array}{l}\text { Porcine reproductive and } \\
\text { respiratory virus }\end{array}$ & orf5 (p25) & Highly cytotoxic (Suarez et al, 1996) \\
\hline \multicolumn{3}{|l|}{ Hepadnaviridae } \\
\hline Hepatitis $B$ virus & $\mathrm{pX}$ & $\begin{array}{l}\text { Cell growth and cell death control via p53 (Chirillo et al, 1997) } \\
\text { Sensitizes cells to TNF-mediated killing (Su and Schneider, 1997) }\end{array}$ \\
\hline \multicolumn{3}{|r|}{ क } \\
\hline \multirow[t]{2}{*}{ Human immunodeficiency virus } & $\begin{array}{l}\text { gp120 } \\
\text { Tat }\end{array}$ & $\begin{array}{l}\text { T cell activation (Brenneman et al, 1988) } \\
\text { Transcription factor, increased oxidative stress (Ehret et al, 1996; Li et } \\
\text { al, 1995) }\end{array}$ \\
\hline & Vpr & Cell cycle arrest and apoptosis (Stewart et al, 1997) \\
\hline $\begin{array}{l}\text { Human T-cell leukemia virus } \\
\text { type I }\end{array}$ & Tax & Increased sensitivity to apoptosis (Yamada T et al, 1994) \\
\hline \multicolumn{3}{|l|}{ Papovaviridae } \\
\hline Poliomavirus & middle $\mathrm{T}$ antigen & Hypersensitivity to TNF- $\alpha$ (Bergqvist et al, 1997) \\
\hline \multicolumn{3}{|l|}{ Parvoviridae } \\
\hline Parvovirus & NSP & Cysteine protease (Snijder et al, 1995) \\
\hline Reoviridae & & \\
\hline Reovirus & $\sigma 1$ & Capsid protein, binds to cell surface (Tyler et al, 1995) \\
\hline Flaviviridae & & \\
\hline Classical swine fever virus & Erns & RNAse and can inhibit protein synthesis (Bruschke et al, 1997) \\
\hline Togaviridae & & \\
\hline Sindbis virus & E2 & Transmembrane glycoprotein (Ubol et al, 1994) \\
\hline
\end{tabular}




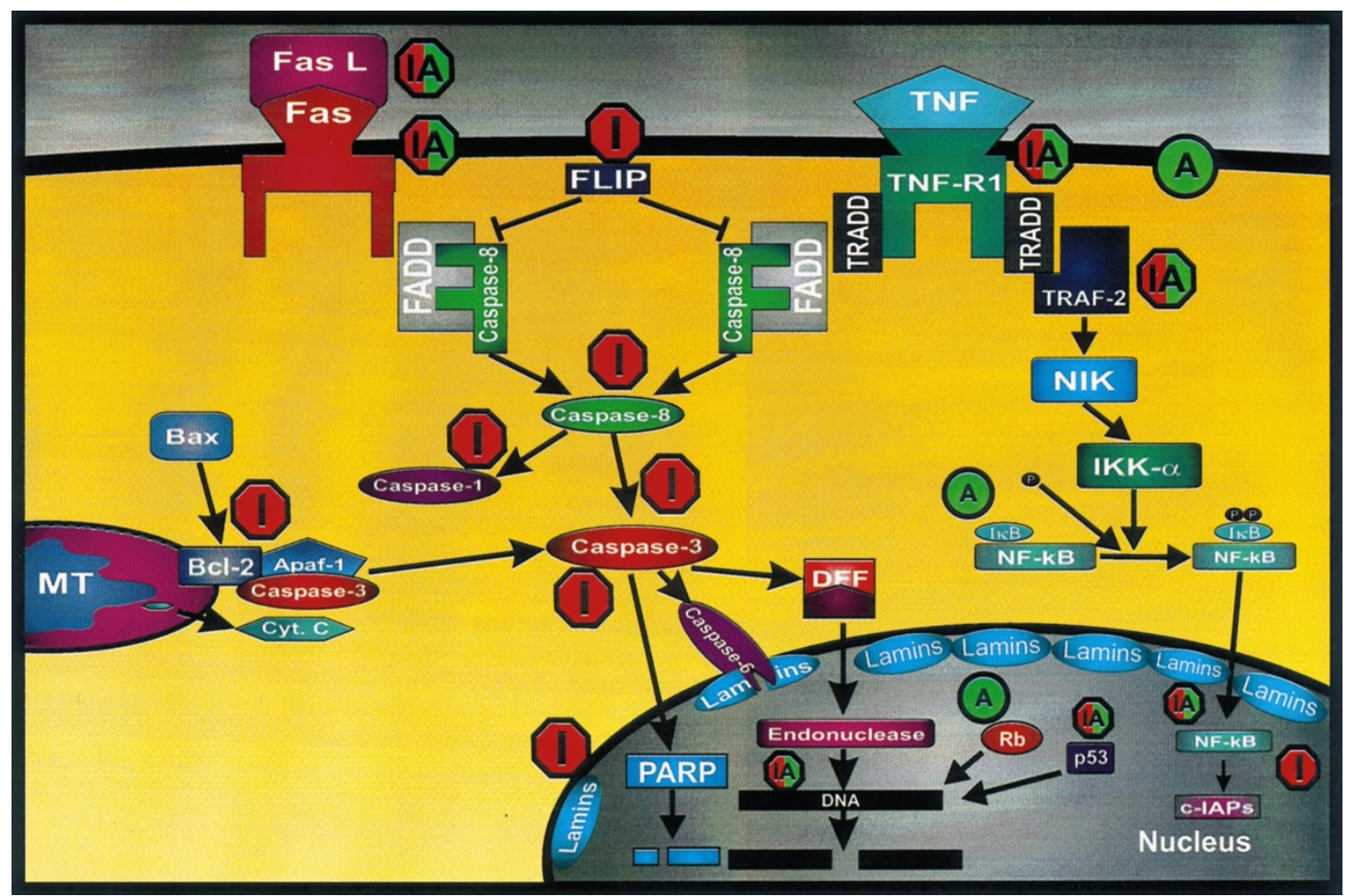

Figure 1 Points of viral protein interaction with host apoptosis-regulatory proteins. Cellular proteins are denoted which interact with viral proteins to either promote (A) or inhibit (I) apoptosis. Several host apoptotic proteins can be either up or downregulated, depending on the virus and the specific viral protein interaction, to produce either a pro-apoptotic or anti-apoptotic effect. Most likely, the state of the virus, the state of the host cell and the stage of infection also determine the probability of apoptosis

However, the E1B $19 \mathrm{~K}$ protein functions to prevent premature E1A-induced apoptosis, thereby permitting the progression of viral replication (White et al, 1991). To facilitate viral release, the adenovirus death protein (ADP or E3 11.6K) induces cell lysis late in the replication cycle, allowing for the release of accumulated viral progeny since apoptosis was blocked by the E1B $19 \mathrm{~K}$ protein (Tollefson et al, 1996a). Cell lysis during the late phase of adenovirus infection is associated with expression of high levels of ADP in contrast to the low levels observed during the early infectious period (Tollefson et al, 1992). Interestingly, cells lysed by adenovirus do not exhibit an apoptotic morphology (Tollefson et al, 1996b) and such programmed necrosis may be unique to these lytic viruses.

Other viral strategies exist for inducing apoptosis. The African swine fever virus encodes a protein homologue (5EL/ $\mathrm{A} 238 \mathrm{~L})$ of the human inhibitor $\kappa \mathrm{B}\left(\mathrm{I}_{\kappa} \mathrm{B}\right)$ protein which binds to nuclear factor $-\kappa \mathrm{B}(\mathrm{NF}-\kappa \mathrm{B})$ and blocks translocation of NF- $\kappa \mathrm{B}$ to the nucleus in response to NF- $\kappa$ B activating stimuli (Neilan et al, 1997). Through such a mechanism the virus may prevent NF- $\kappa \mathrm{B}$-mediated transcription and upregulation of proinflammatory cytokine production which would serve to thwart viral spread (Powell et al, 1996). Furthermore, 5EL may promote apoptosis, since NF- $\kappa \mathrm{B}$ activation is also responsible for the transcription of antiapoptotic genes (Chu et al, 1997). The baculovirus protein, El-1, a transactivator of baculovirus gene expression induces apoptosis by an undefined mechanism (Prikhod'ko and Miller, 1996). The chicken anemia virus encodes a nuclear binding protein, apoptin, which induces p53-independent apoptosis that is not regulated by Bcl-2 (Danen-Van Oorschot et al, 1997; Zhuang et al, 1995b). Interestingly, apoptin induces apoptosis in malignant but not in normal cells although the explanation for this dichotomy is not understood (Danen-Van Oorschot et al, 1997).

Apoptosis is a contributing feature in the chronic liver disease caused by hepatitis B virus (HBV). The HBV protein, $\mathrm{pX}$, is a multi-functional protein which influences cell growth and p53-dependent cell death (Chirillo et al, 1997; Haviv et al, 1996). Further, pX sensitizes otherwise TNF-resistant cells to apoptosis (Su and Schneider, 1997). However, the mechanism of $\mathrm{pX}$-mediated TNF sensitization remains undefined.

Clinically significant virus-induced T-lymphocyte apoptosis is observed in association with human immunodeficiency virus-1 (HIV-1) infection. However, the mechanisms of $\mathrm{T}$ cell death following HIV infection are controversial. It has been demonstrated that CD4+ and CD8+ T lymphocytes of HIV-infected individuals may be primed to undergo apoptosis in response to Fas stimulation, suggesting that Fas signaling may be important in $\mathrm{T}$ lymphocyte death in these patients (Katsikis et al, 1995). The HIV transcription factor Tat may upregulate $\mathrm{T}$ cell Fas ligand expression, thereby contributing to the apoptotic death of Fasexpressing neighboring immune cells (Westendorp et al, 1995). Together, HIV-1 Tat and the CD4 ligand gp120 may 
augment Fas-mediated, activation-induced T cell apoptosis leading to $T$ cell depletion (Brenneman et al, 1988; Westendorp et al, 1995). However, tumor necrosis factorrelated apoptosis-inducing ligand (TRAIL), a member of the TNF/nerve growth factor ligand family, is also capable of triggering activation-induced $\mathrm{T}$ cell death following $\mathrm{HIV}$ infection (Katsikis et al, 1997).

The reovirus $\sigma 1$ protein is responsible for viral binding to an uncharacterized receptor on the surface of target cells which subsequently trigger an apoptotic response (Tyler et al, 1995). Other viruses including the parvovirus (Morey et al, 1993), Sindbis virus (Ubol et al, 1994) and poliovirus (Tolskaya et al, 1995) also induce host cell apoptosis. The mechanisms by which these viruses induce host cell apoptosis are not established.

\section{Conclusion}

Apoptosis is a key host defense mechanism for the elimination of virus-infected cells and to impede the spread of virus. The acquisition of one or more anti-apoptotic genes by different viruses supports the existence of an antagonistic relationship between host and virus. Conversely, other viruses harness the apoptotic pathway to further viral infectivity and pathogenesis (Teodoro and Branton, 1997). Specific interactions between viral and host proteins may be key determinants maintaining cell survival or triggering cell death. With the explosive growth in research in this area, there exists great potential for the development of novel therapeutics to intercede in virally-mediated disease.

\section{References}

Antoku K, Liu Z and Johnson DE (1997) Inhibition of caspase proteases by CrmA enhances the resistance of human leukemic cells to multiple chemotherapeutic agents. Leukemia, 11: 1665-1672

Barco A and Carrasco L (1995) Poliovirus 2Apro expression inhibits growth of yeast cells. FEBS Lett, 371: $4-8$

Bergqvist A, Soderbarg K and Magnusson G (1997) Altered susceptibility to tumor necrosis factor alpha-induced apoptosis of mouse cells expressing polyomavirus middle and small T antigens. J. Virol., 71: 276-283

Bertin J, Armstrong RC, Ottilie S, Martin DA, Wang Y, Banks S, Wang GH, Senkevich TG, Alnemri ES, Moss B, Lenardo MJ, Tomaselli KJ and Cohen JI. (1997) Death effector domain-containing herpesvirus and poxvirus proteins inhibit both Fasand TNFR1-induced apoptosis. Proc. Natl. Acad. Sci. USA, 94: 1172-1176

Bertin J, Mendrysa SM, LaCount DJ, Gaur S, Krebs JF, Armstrong RC, Tomaselli KJ and Friesen PD (1996) Apoptotic suppression by baculovirus P35 involves cleavage by and inhibition of a virus-induced CED-3/ICE-like protease. J. Virol., 70: $6251-6259$

Brenneman DE, Westbrook GL, Fitzgerald SP, Ennist DL, Elkins KL, Ruff MR and Pert CB (1988) Neuronal cell killing by the envelope protein of HIV and its prevention by vasoactive intestinal peptide. Nature, 335: 639-642

Brooks MA, Ali AN, Turner PC and Moyer RW (1995) A rabbitpox virus serpin gene controls host range by inhibiting apoptosis in restrictive cells. J. Virol., 69: 7688 7698

Brown J, Higo H, McKalip A and Herman B(1997) Human papillomavirus (HPV) 16 E6 sensitizes cells to atractyloside-induced apoptosis: role of p53, ICE-like proteases and the mitochondrial permeability transition. J. Cell Biochem., 66: $245-255$

Bruschke CJ, Hulst MM, Moormann RJ, van Rijn PA and van Oirschot JT (1997) Glycoprotein Erns of pestiviruses induces apoptosis in lymphocytes of several species. J. Virol., 71:6692-6696
Chacon MR, Almazan F, Nogal ML, Vinuela E and Rodriguez JF (1995) The African swine fever virus IAP homolog is a late structural polypeptide. Virol., 214: 670674

Cheng EH, Nicholas J, Bellows DS, Hayward GS, Guo HG, Reitz MS and Hardwick JM (1997) A Bcl-2 homolog encoded by Kaposi sarcoma-associated virus, human herpesvirus 8, inhibits apoptosis but does not heterodimerize with Bax or Bak. Proc. Natl. Acad. Sci. USA, 94: 690-694

Chiou SK, Tseng CC, Rao L and White E (1994) Functional complementation of the adenovirus E1B 19-kilodalton protein with Bcl-2 in the inhibition of apoptosis in infected cells. J. Virol., 68: 6553-6566

Chirillo P, Pagano S, Natoli G, Puri PL, Burgio VL, Balsano C and Levrero M (1997) The hepatitis $B$ virus $X$ gene induces $p 53-$ mediated programmed cell death. Proc. Natl. Acad. Sci. USA, 94: 8162-8167

Chu ZL, McKinsey TA, Liu L, Gentry JJ, Malim MH and Ballard DW (1997) Suppression of tumor necrosis factor-induced cell death by inhibitor of apoptosis c-IAP2 is under NF-kappaB control. Proc. Natl. Acad. Sci. USA, 94: 1005710062

Conzen SD, Snay CA and Cole CN (1997) Identification of a novel antiapoptotic functional domain in simian virus 40 large T antigen. J. Virol., 71: 4536-4543

Cuffs S and Ruby J (1996) Evasion of apoptosis by DNA viruses. Immunol. Cell Biol., 74: $527-537$

Danen-Van Oorschot AA, Fischer DF, Grimbergen JM, Klein B, Zhuang S, Falkenburg JH, Backendorf C, Quax PH, Van der Eb AJ and Noteborn $\mathrm{MH}$ (1997) Apoptin induces apoptosis in human transformed and malignant cells but not in normal cells. Proc. Natl. Acad. Sci. USA, 94: 5843-5847

Devereaux QL, Takahashi R, Salvesen GS and Reed JC (1997) X-linked IAP is a direct inhibitor of cell-death proteases. Nature, 388: 300-304

Devergne O, Hatzivassiliou E, Izumi KM, Kaye KM, Kleijnen MF, Kieff E and Mosialos G (1996) Association of TRAF1, TRAF2 and TRAF3 with an Epstein-Barr virus LMP1 domain important for B-lymphocyte transformation: role in NF-kappaB activation. Mol. Cell Biol., 16: 7098-7108

Dimitrov T, Krajcsi P, Hermiston TW, Tollefson AE, Hannink M and Wold WS (1997) Adenovirus E3-10.4K/14.5K protein complex inhibits tumor necrosis factorinduced translocation of cytosolic phospholipase A2 to membranes. J. Virol., 71: $2830-2837$

Dobbelstein M and Shenk T (1996) Protection against apoptosis by the vaccinia virus SPI-2 (B13R) gene product. J. Virol., 70: 6479-6485

Ehret A, Westendorp MO, Herr I, Debatin KM, Heeney JL, Frank R and Krammer PH (1996) Resistance of chimpanzee T cells to human immunodeficiency virus type 1 Tat-enhanced oxidative stress and apoptosis. J. Virol., 70: 6502-6507

Farrow SN, White JH, Martinou I, Raven T, Pun KT, Grinham CJ, Martinou JC and Brown R (1995) Cloning of a bcl-2 homologue by interaction with adenovirus E1B 19K. Nature, 374: $731-733$

Fernandez-Arias A, Martinez S and Rodriguez JF (1997) The major antigenic protein of infectious bursal disease virus, VP2, is an apoptotic inducer. J. Virol., 71: 8014-8018

Fries KL, Miller WE and Raab-Traub N (1996) Epstein-Barr virus latent membrane protein 1 blocks p53-mediated apoptosis through the induction of the A20 gene. J. Virol., 70: 8653-8659

Hardwick JM (1997) Apoptosis: Pharmacological implications and therapeutic opportunities, Vol. 41. Kaufmann SH. (ed.). Academic Press Ltd.: San Diego, pp $295-336$

Haviv I, Vaizel D and Shaul Y (1996) pX, the Hbv-encoded coactivator, interacts with components of the transcription machinery and stimulates transcription in a Tafindependent manner. EMBO J., 15: 3413-3420

Henderson S, Huen D, Rowe M, Dawson C, Johnson G and Rickinson A (1993) Epstein-Barr virus-coded BHRF1 protein, a viral homologue of $\mathrm{Bcl}-2$, protects human B cells from programmed cell death. Proc. Natl. Acad. Sci. USA, 90: $8479-8483$

Ho CK and Shuman S (1996) Physical and functional characterization of the doublestranded RNA binding protein encoded by the vaccinia virus E3 gene. Virology, 217: $272-284$

Hu S, Vincenz C, Buller M and Dixit VM (1997) A novel family of viral death effector domain-containing molecules that inhibit both CD-95- and tumor necrosis factor receptor-1-induced apoptosis. J. Biol. Chem., 272: 9621-9624 
Katsikis PD, Garcia-Ojeda ME, Torres-Roca JF, Tijoe IM, Smith CA Herzenberg LA and Herzenberg LA (1997) Interleukin-1 beta converting enzyme-like protease involvement in Fas- induced and activation-induced peripheral blood T cell apoptosis in HIV infection. TNF-related apoptosisinducing ligand can mediate activation-induced $T$ cell death in HIV infection. J. Exp. Med., 186: 1365-1372

Katsikis PD, Wunderlich ES, Smith CA, Herzenberg LA and Herzenberg LA (1995) Fas antigen stimulation induces marked apoptosis of $T$ lymphocytes in human immunodeficiency virus-infected individuals. J. Exp. Med., 181: 2029-2036

Kettle S, Alcami A, Khanna A, Ehret R, Jassoy C and Smith GL (1997) Vaccinia virus serpin B13R (SPI-2) inhibits interleukin-1 beta- converting enzyme and protects virus-infected cells from TNF-and Fas-mediated apoptosis, but does not prevent IL-1beta-induced fever. J. Gen. Virol., 78: 677-685

Komiyama T, Ray CA, Pickup DJ, Howard AD, Thornberry NA, Peterson EP and Salvesen G (1994) Inhibition of interleukin-1 beta converting enzyme by the cowpox virus serpin CrmA. An example of cross-class inhibition. J. Biol. Chem., 269: $19331-19337$

Krajcsi P, Dimitrov T, Hermiston TW, Tollefson AE, Ranheim TS, Vande Pol SB, Stephenson AH and Wold WS (1996) The adenovirus E3-14.7K protein and the E3-10.4K/14.5K complex of proteins, which independently inhibit tumor necrosis factor (TNF)- induced apoptosis, also independently inhibit TNF-induced release of arachidonic acid. J. Virol., 70: $4904-4913$

Leopardi R, Van Sant C and Roizman B (1997) The herpes simplex virus 1 protein kinase US3 is required for protection from apoptosis induced by the virus. Proc. Natl. Acad. Sci. USA, 94: 7891-7896

Li CJ, Friedman DJ, Wang C, Metelev V and Pardee AB (1995) Induction of apoptosis in uninfected lymphocytes by HIV-1 Tat protein. Science, 268: 429-431

Li H, Lochmuller H, Yong VW, Karpati G and Nalbantoglu J (1997) Adenovirusmediated wild-type p53 gene transfer and overexpression induces apoptosis of human glioma cells independent of endogenous $\mathrm{p} 53$ status. J. Neuropathol. Exp. Neurol., 56: $872-878$

Liu Y and Kitsis RN (1996) Induction of DNA synthesis and apoptosis in cardiac myocytes by E1A oncoprotein. Circulation, 93: 1424-1438

McCarthy NJ, Hazlewood SA, Huen DS, Rickinson AB and Williams GT (1996) The Epstein-Barr virus gene BHRF1, a homologue of the cellular oncogene Bcl-2, inhibits apoptosis induced by gamma radiation and chemotherapeutic drugs. Adv. Exp. Med. Biol., 406: 83-97

Morey AL, Ferguson DJ and Fleming KA (1993) Ultrastructural features of fetal erythroid precursors infected with parvovirus B19 in vitro: evidence of cell death by apoptosis. J. Pathol., 169: 213-220

Nava VE, Cheng EH, Veliuona M, Zou S, ClemRJ, Mayer ML and HardwickJM (1997) Herpesvirus saimiri encodes a functional homolog of the human bcl-2 oncogene. J. Virol., $71: 4118-4122$

Neilan JG, Lu Z, Afonso CL, Kutish GF, Sussman MD and Rock DL (1993) An African swine fever virus gene with similarity to the proto-oncogene bcl-2 and the Epstein-Barr virus gene BHRF1. J. Virol., 67: 4391-4394

Neilan JG, Lu Z, Kutish GF, Zsak L, Lewis TL and Rock DL (1997) A Conserved African Swine Fever Virus IkappaB Homolog, 5EL, Is Nonessential for Growth in Vitro and Virulence in Domestic Swine. Virol., 235: 377-385

Nicholson DW and Thornberry NA (1997) Caspases: killer proteases. Trends in Biochemical Sciences, 22: 299-306

Powell PP, Dixon LK and Parkhouse RM (1996) An lkappaB homolog encoded by African swine fever virus provides a novel mechanism for downregulation of proinflammatory cytokine responses in host macrophages. J. Virol., 70: 8527 8533

Prikhod'ko EA and Miller LK (1996) Induction of apoptosis by baculovirus transactivator IE1. J. Virol., 70: 7116-7124

Querido E, Marcellus RC, Lai A, Charbonneau R, Teodoro JG, Ketner G and Branton PE (1997) Regulation of $p 53$ levels by the E1B 55-kilodalton protein and E4orf6 in adenovirus-infected cells. J. Virol., 71: 3788-3798

Rao L, Debbas M, Sabbatini P, Hockenbery D, Korsmeyer $S$ and White $E$ (1992) The adenovirus E1A proteins induce apoptosis, which is inhibited by the $\mathrm{E} 1 \mathrm{~B} 19-\mathrm{kDa}$ and $\mathrm{Bcl}-2$ proteins [published erratum appears in Proc. Natl. Acad. Sci. USA 1992 Oct 15;89(20):9974]. Proc. Natl. Acad. Sci. USA, 89: $7742-7746$

Rao L, Modha D and White E (1997) The E1B 19K protein associates with lamins in vivo and its proper localization is required for inhibition of apoptosis. Oncogene, 15: $1587-1597$
Ray CA, Black RA, Kronheim SR, Greenstreet TA, Sleath PR, Salvesen GS and Pickup DJ (1992) Viral inhibition of inflammation: cowpox virus encodes an inhibitor of the interleukin-1 beta converting enzyme. Cell, 69: $597-604$

Revilla Y, Cebrian A, Baixeras E, Martinez C, Vinuela E and Salas ML (1997). Inhibition of apoptosis by the African swine fever virus Bcl-2 homologue: role of the BH1 domain. Virol., 228: 400-404

Rudin CM and Thompson CB (1997) Apoptosis and disease: Regulation and clinical relevance of programmed cell death. Annu. Rev. Med., 48: 267-281

Schreiber M, Sedger L and McFadden G (1997) Distinct domains of M-T2, the myxoma virus tumor necrosis factor (TNF) receptor homolog, mediate extracellular TNF binding and intracellular apoptosis inhibition. J. Virol., 71: $2171-2181$

Sedger L and McFadden G (1996) M-T2: a poxvirus TNF receptor homologue with dual activities. Immunol. Cell Biol., 74: 538-545

Senkevich TG, Koonin EV, Bugert JJ, Darai G and Moss B (1997) The genome of molluscum contagiosum virus: analysis and comparison with other poxviruses. Virol., 233: 19-42

Shisler J, Yang C, Walter B, Ware CF and Gooding LR (1997) The adenovirus E3$10.4 \mathrm{~K} / 14.5 \mathrm{~K}$ complex mediates loss of cell surface Fas (CD95) and resistance to Fas-induced apoptosis. J. Virol., 71: 8299-8306

Snijder EJ, Wassenaar AL, Spaan WJ and Gorbalenya AE (1995) The arterivirus Nsp2 protease. An unusual cysteine protease with primary structure similarities to both papain-like and chymotrypsin-like proteases. J. Biol. Chem., 270: $16671-16676$

Srinivasula SM, Ahmad M, Fernandes-Alnemri T, Litwack G and Alnemri ES (1996) Molecular ordering of the Fas-apoptotic pathway: the Fas/APO-1 protease Mch5 is a CrmA-inhibitable protease that activates multiple Ced-3/ICE-like cysteine proteases. Proc. Natl. Acad. Sci. USA, 93: 14486-14491

Stewart SA, Poon B, Jowett JB and Chen IS (1997) Human immunodeficiency virus type 1 Vprinduces apoptosis following cell cycle arrest. J. Virol., 71: 5579-5592

Su F and Schneider RJ (1997) Hepatitis B virus HBx protein sensitizes cells to apoptotic killing by tumor necrosis factor alpha. Proc. Natl. Acad. Sci. USA, 94: $8744-8749$

Suarez P, Zardoya R, Martin MJ, Prieto C, Dopazo J, Solana A and Castro JM (1996) Phylogenetic relationships of european strains of porcine reproductive and respiratory syndrome virus (PRRSV) inferred from DNA sequences of putative ORF-5 and ORF-7 genes. Virus Res., 42: 159-165

Teodoro J and Branton P (1997) Regulation of Apoptosis by Viral Gene Products. J. Virol., 71 : $1739-1746$

Thome M, Schneider P, Hofmann K, Fickenscher H, Meinl E, Neipel F, Mattmann C, Burns K, Bodmer J, Schroter M, Scaffidi C, Krammer P, Peter ME and Tschopp J (1997) Viral FLICE-inhibitory proteins (FLIPs) prevent apoptosis induced by death receptors. Nature, 386: 517-521

Thompson CB (1995) Apoptosis in the pathogenesis and treatment of disease. Science, 267: 1456-1461

Tollefson AE, Ryerse JS, Scaria A, Hermiston TW and Wold WS (1996a) The E311.6-kDa adenovirus death protein (ADP) is required for efficient cell death: characterization of cells infected with adp mutants. Virol., 220: 152-162

Tollefson AE, Scaria A, Hermiston TW, Ryerse JS, Wold LJ and Wold WS (1996b) The adenovirus death protein (E3-11.6K) is required at very late stages of infection for efficient cell lysis and release of adenovirus from infected cells. J. Virol., 70: 2296-2306

Tollefson AE, Scaria A, Saha SK and Wold WS (1992) The 11,600-MW protein encoded by region $\mathrm{E} 3$ of adenovirus is expressed early but is greatly amplified at late stages of infection. J. Virol., 66: 3633-3642

Tolskaya EA, Romanova LI, Kolesnikova MS, Ivannikova TA, Smirnova EA, Raikhlin NT and Agol VI (1995) Apoptosis-inducing and apoptosis-preventing functions of poliovirus. J. Virol., 69: 1181-1189

Tufariello JM, Cho S and Horwitz MS (1994) Adenovirus E3 14.7-kilodalton protein, an antagonist of tumor necrosis factor cytolysis, increases the virulence of vaccinia virus in severe combined immunodeficient mice. Proc. Natl. Acad. Sci. USA, 91: 10987-10991

Tyler KL, Squier MK, Rodgers SE, SchneiderBE, Oberhaus SM, Grdina TA, Cohen JJ and Dermody TS (1995) Differences in the capacity of reovirus strains to induce apoptosis are determined by the viral attachment protein sigma 1. J. Virol., 69: 6972-6979

Ubol S, Tucker PC, Griffin DE and Hardwick JM (1994) Neurovirulent strains of Alphavirus induce apoptosis in bcl-2- expressing cells: role of a single amino acid change in the E2 glycoprotein. Proc. Natl. Acad. Sci. USA, 91: 5202-5206 
Uren AG, Pakusch M, Hawkins CJ, Puls KL and Vaux DL (1996) Cloning and expression of apoptosis inhibitory protein homologs that function to inhibit apoptosis and/or bind tumor necrosis factor receptor-associated factors. Proc. Natl. Acad. Sci. USA, 93: 4974-4978

Wang GH, Bertin J, Wang Y, Martin DA, Wang J, Tomaselli KJ, Armstrong RC and Cohen JI. (1997) Bovine herpesvirus 4 BORFE2 protein inhibits Fas- and tumor necrosis factor receptor 1-induced apoptosis and contains death effector domains shared with other gamma-2 herpesviruses. J. Virol., 71: 8928-8932

Westendorp MO, Frank R, Ochsenbauer C, Stricker K, Dhein J, Walczak H, Debatin KM and KrammerPH(1995) Sensitization of T cells to CD95-mediated apoptosis by HIV-1 Tat and gp120. Nature, 375: 497-500

White E, Cipriani R, Sabbatini P and Denton A (1991) Adenovirus E1B 19-kilodalton protein overcomes the cytotoxicity of E1A proteins. J. Virol., 65: 2968-2978

Wold WS (1993) Adenovirus genes that modulate the sensitivity of virus-infected cells to lysis by TNF. J. Cell Biochem., 53: 329-335

Yamada T, Yamaoka S, Goto T, Nakai M, Tsujimoto Y and Hatanaka M (1994) The human T-cell leukemia virus type I Tax protein induces apoptosis which is blocked by the Bcl-2 protein. J Virol., 68: 3374-3379
Yew PR, Liu X and Berk AJ (1994) Adenovirus E1B oncoprotein tethers a transcriptional repression domain to p53. Genes Dev., 8: 190-202

Yuan J (1997) Transducing signals of life and death. Curr. Opin. Cell Biol., 9: 247 251

Zhou Q, Snipas S, Orth K, Muzio M, Dixit VMand Salvesen GS (1997) Target protease specificity of the viral serpin CrmA. Analysis of five caspases. J. Biol. Chem., 272: $7797-7800$

Zhu H, Shen Y and Shenk T (1995) Human cytomegalovirus IE1 and IE2 proteins block apoptosis. J. Virol., 69: 7960-7970

Zhuang SM, Landegent JE, Verschueren CA, Falkenburg JH, van Ormondt $\mathrm{H}$, van der Eb AJ and Noteborn MH (1995a) Apoptin, a protein encoded by chicken anemia virus, induces cell death in various human hematologic malignant cells in vitro. Leukemia, 9: S118-S120

Zhuang SM, Shvarts A, Jochemsen AG, van Oorschot AA, van der Eb AJ and Noteborn MH (1995b) Differential sensitivity to Ad5 E1B-21kD and Bcl-2 proteins of apoptin- induced versus p53-induced apoptosis. Carcinogenesis, 16: 2939 2944 